University of Nebraska - Lincoln

DigitalCommons@University of Nebraska - Lincoln

\title{
Distribution and Prevalence of Echinococcus multilocularis in Wild Predators in Nebraska, Kansas, and Wyoming
}

\author{
S. T. Stroandt \\ Purdue University \\ D. R. Virchow \\ University of Nebraska - Lincoln \\ M. W. Dryden \\ Kansas State University \\ Scott E. Hygnstrom \\ University of Nebraska - Lincoln, shygnstrom1@unl.edu \\ K. R. Kazacos \\ Purdue University
}

Follow this and additional works at: https://digitalcommons.unl.edu/natrespapers

Part of the Parasitology Commons, Terrestrial and Aquatic Ecology Commons, and the Zoology

Commons

Stroandt, S. T.; Virchow, D. R.; Dryden, M. W.; Hygnstrom, Scott E.; and Kazacos, K. R., "Distribution and Prevalence of Echinococcus multilocularis in Wild Predators in Nebraska, Kansas, and Wyoming" (2002). Papers in Natural Resources. 369.

https://digitalcommons.unl.edu/natrespapers/369

This Article is brought to you for free and open access by the Natural Resources, School of at DigitalCommons@University of Nebraska - Lincoln. It has been accepted for inclusion in Papers in Natural Resources by an authorized administrator of DigitalCommons@University of Nebraska - Lincoln. 


\section{Distribution and Prevalence of Echinococcus multilocularis in Wild Predators in Nebraska, Kansas, and Wyoming}

S. T. Storandt, D. R. Virchow ${ }^{\star}$, M. W. Dryden†, S. E. Hygnstrom, and K. R. Kazacos, Department of Veterinary Pathobiology, Purdue University, West Lafayette, Indiana 47907-1243; *School of Natural Resource Sciences, University of Nebraska, Lincoln, Nebraska 68583-0758; †Department of Diagnostic Medicine and Pathobiology, Kansas State University, Manhattan, Kansas 66506. e-mail: kkazacos@purdue.edu

ABSTRACT: To further determine the distribution and prevalence of Echinococcus multilocularis in the central United States, 245 wild canids (125 red foxes, 120 coyotes) and 33 bobcats were collected from Nebraska, Kansas, and Wyoming and examined for this parasite. Ani- mals examined included 11 red foxes from the western panhandle of Nebraska; 5 red foxes and 30 coyotes from southern Nebraska; 56 red foxes and 1 coyote from northeastern Nebraska; 20 red foxes, 63 coyotes, and 13 bobcats from northern Kansas; 2 red foxes, 26 coyotes, 
and 20 bobcats from southern Kansas; and 31 red foxes from eastcentral Wyoming. Of these, 27 of $72(37.5 \%)$ red foxes from Nebraska were positive, including 2 of $11(18.2 \%)$ from the western panhandle and 25 of $56(44.6 \%)$ from the northeastern part of the state. Mean intensity of infection was 282 worms (range, $1-5,150$ ). New distribution records were established for E. multilocularis in western Nebraska as well as for several northeastern counties. These findings support previous estimates that the southernmost front of the parasite's range extends along the southern border of Wyoming, eastward through central Nebraska and central Illinois into Indiana and Ohio.

In North America, Echinococcus multilocularis occurs in 2 endemic areas: 1 encompassing the tundra zone of Alaska and Canada and the other the central part of the continent (Rausch, 1985, 1995). In the latter area, the parasite has been reported from 3 Canadian provinces and 11 contiguous states and has been found as far east as Ohio (Storandt and Kazacos, 1993). In the central region, the primary definitive hosts are red foxes (Vulpes vulpes) and coyotes (Canis latrans). Meadow voles (Microtus pennsylvanicus) and deer mice (Peromyscus maniculatus) are the main intermediate hosts (Hildreth et al., 1991). Because of the abundance of suitable hosts in areas surrounding the known endemic region, further spread of E. multilocularis is anticipated (Rausch, 1995). To further determine the distribution and prevalence of E. multilocularis in the central United States, wild canids and bobcats (Lynx rufus) from Nebraska, Kansas, and Wyoming were examined for this parasite.

During 1991-1992 (in Kansas) and 1994-1996 (Nebraska and Wyoming), 245 wild canids (125 red foxes, 120 coyotes) and 33 bobcats were collected and examined for E. multilocularis. Most were collected from participating fur buyers and trappers during the fall and winter trapping seasons, and some were supplied by USDA-APHIS Wildlife Services personnel. The small intestine was ligated, removed, doublebagged, frozen, and later processed and examined for E. multilocularis at Purdue University as previously described (Storandt and Kazacos, 1993). Representative specimens have been deposited in the U.S. National Parasite Collection (USNPC 091271.00).

Animals examined included 11 red foxes from the western panhandle of Nebraska; 5 red foxes and 30 coyotes from southern Nebraska; 56 red foxes and 1 coyote from northeastern Nebraska; 20 red foxes, 63 coyotes, and 13 bobcats from northern Kansas; 2 red foxes, 26 coyotes, and 20 bobcats from southern Kansas; and 31 red foxes from eastcentral Wyoming. Of these, 27 of $72(37.5 \%)$ red foxes from Nebraska were positive, including 2 of $11(18.2 \%)$ from the western panhandle and 25 of $56(44.6 \%)$ from the northeastern part of the state (Table I; Fig. 1). Mean intensity of infection was 282 worms (range, 1-5,150).

In Nebraska, E. multilocularis was collected from red foxes taken in the counties listed in Table I. No positive animals were collected from the following counties in Nebraska, Kansas, or Wyoming (number of animals examined in parentheses; $\mathrm{F}=$ red fox, $\mathrm{C}=$ coyote, $\mathrm{B}=$ bobcat)—Nebraska: Chase (1C), Clay (1C), Colfax (2F), Dawson (4F, 9C), Dodge (1C), Dundy (3C), Fillmore (1C), Franklin (3C), Frontier (1F), Furnas (2C), Hitchcock (2C), Lincoln (1C), Morrill (1F), Nuckolls (2C), Red Willow (2C), Webster (3C); Kansas: Chase (1F, 12C, 7B), Clay (1F, 2C), Coffey (11C, 10B), Ellis (1F), Graham (10C, 1B), Harper (1C),

TABLE I. Echinococcus multilocularis infection in red foxes in $\mathrm{Ne}-$ braska (1994-1996).

\begin{tabular}{|c|c|c|c|}
\hline \multirow[b]{2}{*}{ County } & \multirow{2}{*}{$\begin{array}{c}\text { Number } \\
\text { examined }\end{array}$} & \multicolumn{2}{|c|}{ Infected } \\
\hline & & Number & $\%$ \\
\hline Burt & 5 & 2 & 40.0 \\
\hline Box Butte & 4 & 1 & 25.0 \\
\hline Cuming & 7 & 4 & 57.1 \\
\hline Dodge & 16 & 10 & 62.5 \\
\hline Platte & 12 & 3 & 25.0 \\
\hline Saunders & 7 & 2 & 28.6 \\
\hline Scotts Bluff & 6 & 1 & 16.7 \\
\hline Thurston & 6 & 3 & 50.0 \\
\hline Unknown (northeast) & 1 & 1 & 100.0 \\
\hline
\end{tabular}

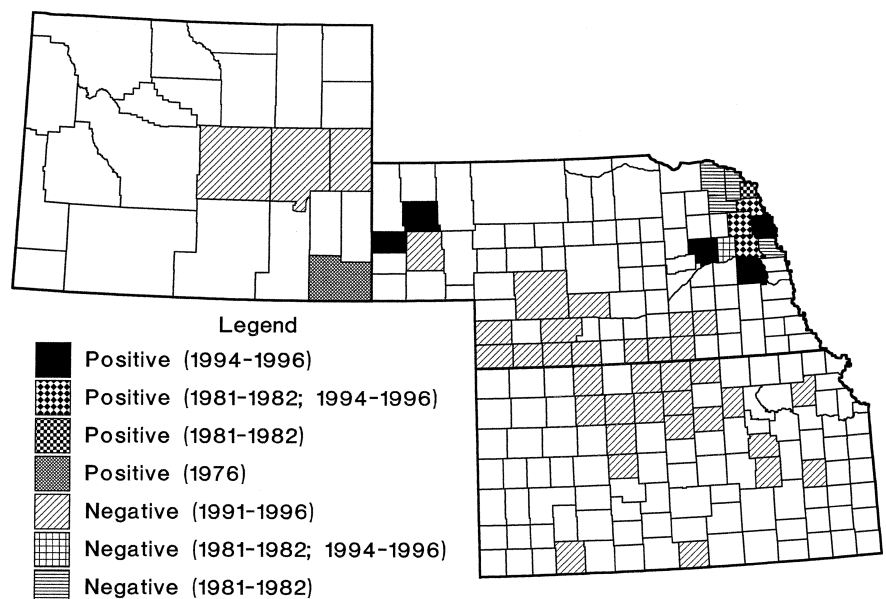

FIGURE 1. Distribution of Echinococcus multilocularis in wild canids in Nebraska, Kansas, and Wyoming, including data for Nebraska from Ballard and Vande Vusse (1983), and for a rodent infection in Wyoming from Kritsky et al. (1977).

Jackson (5F, 12C, 1B), Jewell (2C), Lincoln (9C, 3B), Meade (1F, 2C, 1B), Mitchell (1F, 3C, 3B), Morris (2B), Norton (10C, 1B), Osborne (1F, 9C), Ottawa (4F), Republic (1F, 4B), Rooks (1C), Rush (4C), Smith (6F, 1C); Wyoming: Converse (2F), Natrona (13F), Niobrara (5F), and unknown of latter 3 counties $(11 \mathrm{~F})$.

Since it was first discovered in the north-central United States in the mid-1960s (Leiby and Olsen, 1964), Echinococcus multilocularis has steadily expanded its range to include all or part of 11 contiguous states. The parasite was found in wild canids or rodents in South Dakota, Iowa, Minnesota, and Montana in 1965-1969 (Carney and Leiby, 1968; Leiby et al., 1970; Rausch and Richards, 1971); in a wild woodrat in southeastern Wyoming in 1976 (Kritsky et al., 1977); and in wild canids in northeastern Nebraska and northern Illinois in 1981-1982 (Ballard and Vande Vusse, 1983), in Wisconsin in 1982-1983 (Ballard, 1984), and in northern Indiana, northwestern Ohio, and east-central Illinois in 1990-1991 (Storandt and Kazacos, 1993). Annual surveys conducted in eastern South Dakota in 1987-1991 found a high prevalence of infection in red foxes in that area $(64.0-88.9 \%$, mean $74.5 \%$; Hildreth et al., 2000). In the early 1990s, it was estimated that the southernmost front of the parasite's range extended along the southern border of $\mathrm{Wy}$ oming, eastward through central Nebraska and central Illinois into Indiana and Ohio (Hildreth et al., 1991; Storandt and Kazacos, 1993). Results of the present study further support this assertion because $E$. multilocularis was not found south of a line through central Nebraska (Fig. 1). The parasite was not detected in 35 wild canids from southern Nebraska or 111 wild canids and 33 bobcats from Kansas (Fig. 1).

Echinococcus multilocularis has a much lower prevalence in wild canids in western Nebraska and Wyoming compared to northeastern Nebraska, in that only 2 of $42(4.8 \%)$ red foxes from the west were infected versus 25 of $56(44.6 \%)$ red foxes from the northeast. Presumably, this same pattern would hold true for coyotes but could not be assessed because only a single coyote was examined from the northeastern counties and none from the west. In other studies, coyotes have been found to be as susceptible to infection with $E$. multilocularis as red foxes and, in several cases, to have a higher prevalence and intensity of infection. For example, in Indiana, $22.5 \%$ of 71 red foxes and $18.6 \%$ of 70 coyotes were infected, and in Illinois, $35.3 \%$ of 17 coyotes carried the parasite. Mean intensity of infection for red foxes was 372 worms (range, 2-3,640) versus 6,579 worms (range, 1-52,000) for coyotes (Storandt and Kazacos, 1993).

Coyotes typically have a more diverse diet than red foxes, eating rabbits, hares, and other larger mammals, in addition to rodents. However, even though they consume fewer rodents than do red foxes (Voigt and Berg, 1987), they eat enough rodents to contact the larval cestode and become infected with E. multilocularis. It is well known that a very low prevalence of larval infection in rodents in an area is sufficient to maintain moderate to high levels of infection in wild canids (Rausch, 
1995). It is likely that infected coyotes are more important in the spread of this parasite because they typically have larger home ranges and can travel much longer distances than red foxes (Voigt and Berg, 1987). Suitable intermediate hosts for E. multilocularis occur in all of the areas examined in the present study. Therefore, the absence of E. multilocularis in wild canids in southern Nebraska, Kansas, and east-central Wyoming either reflects the absence of the parasite in these areas (southern Nebraska, Kansas) or a sufficiently low prevalence $(<1-2 \%$ in canids so that it was not detected based on the number of hosts examined. Continued vigilance is necessary to monitor the distribution, prevalence, and spread of this important parasite in different areas of central North America.

We thank the fur buyers of Nebraska and Kansas, particularly S\&D Furs, Tate Hide and Fur Co., Petzka Furs, and Bo Viter; Nebraska field personnel of USDA-APHIS Wildlife Services; and Lloyd Fox of the Kansas Department of Wildlife and Parks, who provided animals for this investigation. We also thank David E. Williams, State Director of USDA-APHIS Wildlife Services, and Chuck McCullough of the Nebraska Game and Parks Commission, for facilitating this study and Ralph Gann and Susan Reynolds of the Indiana Agricultural Statistics Service for help in preparing Figure 1.

\section{LITERATURE CITED}

BALlARD, N. B. 1984. Echinococcus multilocularis in Wisconsin. Journal of Parasitology 70: 844 .

, AND F. J. VANDE VUSSE. 1983. Echinococcus multilocularis in Illinois and Nebraska. Journal of Parasitology 69: 790-791.

CARNEY, W. P., AND P. D. LEIBY. 1968. Echinococcus multilocularis in Peromyscus maniculatus and Vulpes vulpes in Minnesota. Journal of Parasitology 54: 714.

Hildreth, M. B., M. D. Johnson, And K. R. Kazacos. 1991. Echino- coccus multilocularis: A zoonosis of increasing concern in the United States. Compendium on Continuing Education for the Practicing Veterinarian 13: 727-741.

, S. Sriram, B. Gottstein, M. Wilson, and P. M. Schantz. 2000. Failure to identify alveolar echinococcosis in trappers from South Dakota in spite of high prevalence of Echinococcus multilocularis in wild canids. Journal of Parasitology 86: 75-77.

Kritsky, D. C., P. D. Leiby, AND G. E. Miller. 1977. The natural occurrence of Echinococcus multilocularis in the bushy-tailed woodrat, Neotoma cinerea rupicola, in Wyoming. American Journal of Tropical Medicine and Hygiene 26: 1046-1047.

LeIBY, P. D., W. P. CARNEY, AND C. E. WoOdS. 1970. Studies on sylvatic echinococcosis. III. Host occurrence and geographic distribution of Echinococcus multilocularis in the north central United States. Journal of Parasitology 56: 1141-1150.

- AND O. W. OLSEN. 1964. The cestode Echinococcus multilocularis in foxes in North Dakota. Science 145: 1066.

Rausch, R. L. 1985. Parasitology: Retrospect and prospect. Journal of Parasitology 71: 139-151.

. 1995. Life cycle patterns and geographic distribution of Echinococcus species. In Echinococcus and hydatid disease, R. C. A Thompson and A. J. Lymbery (eds.). CAB International, Wallingford, U. K., p. 89-134.

, AND S. H. RICHARDS. 1971. Observations on parasite-host relationships of Echinococcus multilocularis Leuckart, 1863, in North Dakota. Canadian Journal of Zoology 49: 1317-1330.

StORANDT, S. T., AND K. R. KAZACOS. 1993. Echinococcus multilocularis identified in Indiana, Ohio, and east-central Illinois. Journal of Parasitology 79: 301-305.

Voigt, D. R., AND W. E. BERG. 1987. Coyote. In Wild furbearer management and conservation in North America, M. Novak, J. A. Baker, M. E. Obbard, and B. Malloch (eds.). Ontario Ministry of Natural Resources, Toronto, Canada, p. 344-357. 